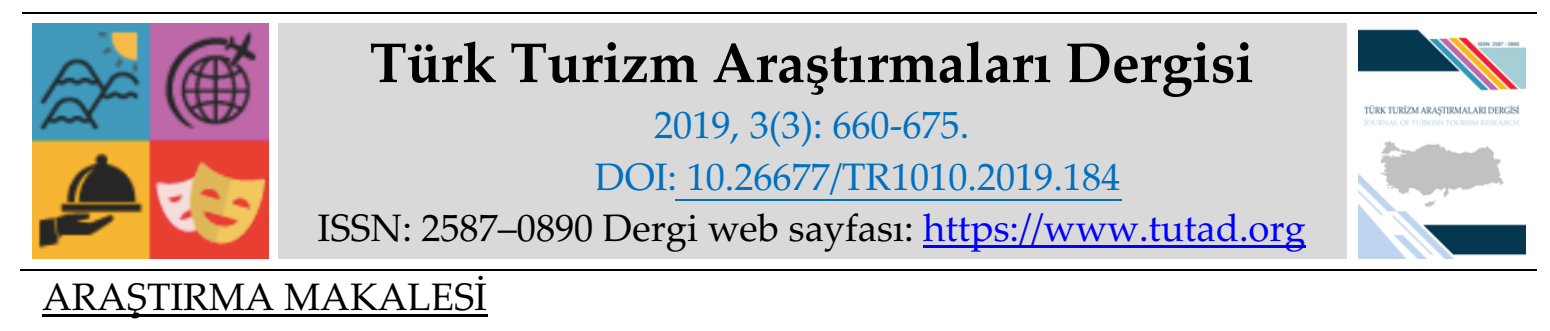

\title{
Arap Turistlerin Türklere Yönelik Önyargılarının Değerlendirilmesi: Doğu Karadeniz Bölgesi Örneği
}

Dr. Öğr. Üyesi Gencay SAATCI, Çanakkale Onsekiz Mart Üniversitesi, Turizm Fakültesi, Çanakkale, e-posta:-gencaysaatci@comu.edu.tr ORCID: https://orcid.org/0000-0002-7842-989X

Arş. Gör. Dr. Özge GÜDÜ DEMIRBULAT, Düzce Üniversitesi, Akçakoca Turizm İşletmeciliği ve Otelcilik Yüksekokulu, Akçakoca, e-posta:ozgegudu@hotmail.com

ORCID: https://orcid.org/0000-0001-7652-7966

Öz

Turizm, kültürlerarası etkileşim süreçlerine ortam hazırlamaktadır. Bu durum, farklı milliyetlerin birbirlerine karşı olan tutumlarının da incelenmesini gerekli bir alan haline getirmiştir. Nitekim etkileşim süreçlerinde birbirlerinin kültürel farklılıklarını göz ardı ederek tutum geliştiren taraflarda, tehdit algılaması söz konusu olabilmektedir. Algılanan tehditler ise; bütünleşik tehdit teorisini kapsayan, gerçekçi tehditler, sembolik tehditler, olumsuz yargılar ve gruplar arası kaygı olmak üzere dört tehdit çeşidinden oluşmaktadır. Bu araştırmada, Doğu Karadeniz Bölgesi'ne gelen Arap turistlerin, "Bütünleşik Tehdit Teorisi” çerçevesinde, Türklere karşı önyargılı yaklaşıp yaklaşmama durumlarının araştırılması amaçlanmıştır. Bu amaç doğrultusunda; Nisan-Haziran 2019 tarihlerinde Doğu Karadeniz Bölgesi'ni ziyaret eden 410 Arap turiste anket uygulaması gerçekleştirilmiştir. Araştırma sonucunda; Arap turistlerin çoğunluğunun Türklerle iletişim kurmaktan çekinmediği ve Türklerin birbirine benzer tutuma sahip olmadığını düşündükleri belirlenmiştir. Ayrıca Arap turistlerin Doğu Karadeniz Bölgesi'ni ziyaretleri boyunca algılamış oldukları bütünleşik tehditlerin, Türklere karşı önyargılı davranmalarına neden olduğu sonucuna ulaşılmıştır. Bu araştırmada, Arap turistler için; gerçekçi tehditlerin, sembolik tehditlerin, olumsuz yargıların, gruplar arası kaygıların ve bütünleşik tehditlerin algılanması ile Türklere karşı önyargılı davranmalarının arasında anlaml, pozitif yönde ve orta düzeyde bir ilişki olduğu tespit edilmiştir.

Anahtar Kelimeler: Bütünleşik Tehdit Teorisi, Kültürel Farklılık, Önyarg1, Arap Turistler, Doğu Karadeniz Bölgesi.

Makale Gönderme Tarihi: 20.05.2019

Makale Kabul Tarihi: 02.07.2019

\section{Önerilen Atıf:}

Saatc1, G. ve Güdü Demirbulat, Ö. (2019). Arap Turistlerin Türklere Yönelik Önyargılarının Değerlendirilmesi: Doğu Karadeniz Bölgesi Örneği, Türk Turizm Araştırmaları Dergisi, 3(3): 660675.

(C) 2019 Türk Turizm Araştırmaları Dergisi. 


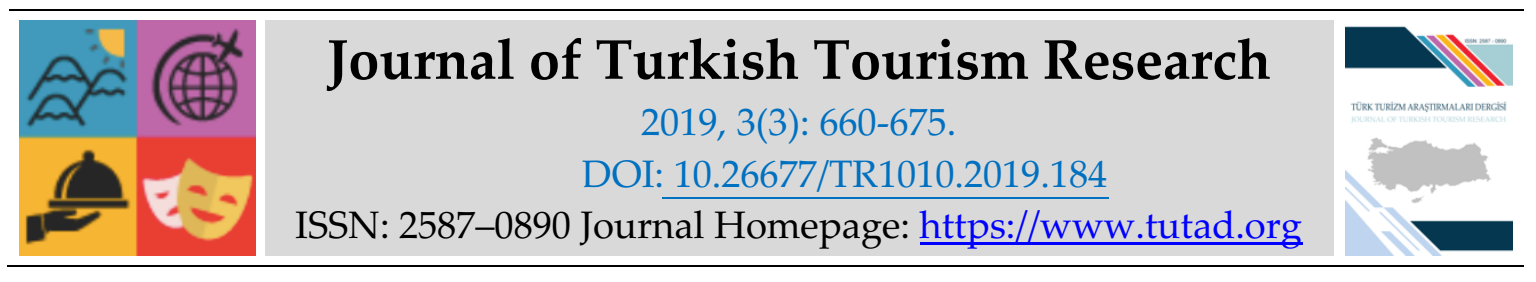

\title{
$\underline{\text { RESEARCH PAPER }}$
}

\section{Assessments of the Prejudices of the Arab Tourists Against Turks: An Example of Eastern Black Sea Region}

Assistant Prof. Dr. Gencay SAATCI, Çanakkale Onsekiz Mart University, Faculty of Tourism, email:gencaysaatci@comu.edu.tr ORCID: https://orcid.org/0000-0002-7842-989X

Dr. Özge GÜDÜ DEMIRBULAT, Düzce University, Akçakoca School of Tourism and Hotel Management, Akçakoca, e-mail:ozgegudu@hotmail.com ORCID: https://orcid.org/0000-0001-7652-7966

\begin{abstract}
Tourism prepares the environment for cross-cultural interaction processes. This situation made it necessary to examine the attitudes of different nationalities towards each other. In the interaction process of the tourists, because they develop an attitude by ignoring the cultural differences, a threat perceive happens for both sides. The perceived threats which contains integrated threat theory is composed of four threats such as real threats, symbolic threats, wrong judices, cross-group anxiety. In this study, it is aimed to investigate the prejudice of the tourists coming from the Arab countries to the Eastern Black Sea Region within the framework of "Integrated Threat Theory". In accordance with this purpose; a survey was conducted on 410 Arab tourists visiting the Eastern Black Sea Region in April-June 2019. As a result of the research; it was determined that the majority of Arab tourists did not hesitate to communicate with the Turks and that the Turks did not have similar attitudes. Moreover; it was concluded that the integrated threats perceived by Arab tourists during their visit to the Eastern Black Sea Region caused prejudice against the Turks. Consequently, for Arab tourists; it was found that there is a significant, positive and moderate relationship between the perception of real threats, symbolic threats, wrong judices, cross-group anxiety, integrated threats and their prejudice against Turks.
\end{abstract}

Keywords: Integrated Threat Theory, Cultural Difference, Prejudice, Attitude, Arab Tourists, Black Sea Region.

Received: 20.05.2019

Accepted: 02.07.2019

Suggested Citation:

Saatcl, G. and Güdü Demirbulat, Ö. (2019). Assessments of the Prejudices of the Arab Tourists Against Turks: An Example of Eastern Black Sea Region, Journal of Turkish Tourism Research, 3(3): 660-675.

(C) 2019 Türk Turizm Araştırmaları Dergisi. 


\section{Gíriş}

Küreselleşmenin yarattığı ortam ile birlikte bireylerin birbirlerine karşı olan tutumları da incelenmesi gereken bir alan haline gelmiştir. Farklı kültürden insanlar ile iletişim ve etkileşim halinde bulunulurken; dil ve iletişim kalıplarının (göz hareketleri, göz teması, el ve kol hareketleri, iletişim mesafesi) ve davranışların ne anlam ifade ettiklerinin bilinmesi gerekmektedir. Örneğin Kuzey Amerika'da bireyler arasında kurulan göz teması saygıyı, Kore'de ise saygısızlığı ifade ederken; Arap ülkelerinde kadın ile yabancı erkeğin göz teması doğru karşılanmamaktadır ve Orta Doğu'da da kadınlar erkekler ile el sıkışmamaktadırlar (Bayık Temel, 2011). Özellikle bireylerin etkileşim süreçleri içerisinde birbirlerinin kültürel farklılıklarını göz ardı ederek tutum geliştirmeleri sonucu, taraflarda tehdit algılaması gerçekleşmektedir. Algılanan tehditler ise; bütünleşik tehdit teorisini kapsayan, gerçekçi tehditler, sembolik tehditler, olumsuz yargılar ve gruplararası kaygı olmak üzere dört faktörden oluşmaktadır. Bütünleşik tehditlerin algılanması sonucunda ise ortaya olumsuz düşünceler ve önyargılar çıkmaktadır. Bireylerin etkileşim sürecinde birbirlerine önyargılı davranmaları, gruplar arasında gerginlikler ve ayrımcı davranışlar da yaşanmasına neden olmaktadır. Farklı kültür ve bakış açlarına sahip olan insanlar arasında herhangi bir etkileşim ya da iletişim olduğu zaman, kaçınılmaz olarak anlaşmazlıklar da ortaya çıkabilecektir (Ruggiero, 2013).

Dünya'da ve Arap ülkelerinde son 15 yılda yaşanan gelişmeler başta 11 Eylül ve Arap Baharı olayları olmak üzere Körfez ülkeleri vatandaşlarının turizm tercihlerinde rol oynayan en önemli gelişmelerdir (DOKA, 2015). Günümüzde uluslararası turizm pazarında önemli bir yere sahip olan Arap dünyası, Türkiye'de de turizm talebini etkileyecek düzeydedir. Arap Baharı'nın başladığ1 2010 yılından sonraki yıllarda Türkiye'ye gelen Arap turist sayısında artış görülmektedir. Nitekim Türkiye'ye gelen yabancı turistlerin ortalama 4 katı fazla harcama yapan Arap turistlerin sayısı her yıl ortalama \%35 artmaktadır. T.C. Kültür ve Turizm Bakanlığı verilerine göre 2018 yılında Arap ülkelerinden (Mısır, Sudan, Cezayir, Irak, Fas, Suudi Arabistan, Yemen, Suriye, Somali, Tunus, Birleşik Arap Emirlikleri, Ürdün, Libya, Lübnan, Filistin, Umman, Kuveyt, Moritanya, Katar, Bahreyn, Cibuti, Batı Sahra) 4.784.622 kişi Türkiye'yi ziyaret etmiştir (yigm.ktb.gov.tr, 2019). Öte yandan; Türkiye'ye gelen Arap turistlerin özellikle doğa turizmini tercih ettikleri, bunun için de yeşilin daha yoğun olduğu Bursa, Yalova, Trabzon, Rize vb. illere daha çok rağbet gösterdikleri bilinmektedir. Özellikle sıcak yaz dönemlerinde yeşil ile suyun buluştuğu serin ve sakin yerler (Trabzon/Uzungöl, Rize/Ayder Yaylası vb.) Arap turistler tarafından en çok ziyaret edilen yerler arasındadır (Bayram, 2016: 1687; Çeken vd., 2018: 402; DOKA, 2015). Arap turistlerin, Doğu Karadeniz Bölgesini ziyaretleri süresince algıladıkları bütünleşik tehditlerin, Türklere karşı önyargılı davranmalarına neden olabileceği varsayılarak bu araştırma gerçekleştirilmiştir.

\section{LIITERATÜR}

Bir toplumun kültürünü ve toplumlar arasındaki kültürel farklılıkları anlamak çok önemlidir. Kültürel farklılıklar, her bireyin farklı davranması sonucunu ortaya çıkarmaktadır (Reisinger ve Turner, 1997). Kültürel grupları anlamak konusunda; zaman zaman güçlüklerle karşılaşılmaktadır ve çoğu kez konu etraflıca araştırılmadan basmakalıp (stereotype) olarak genelleme yapılmaktadır. Oysa bu doğru bir değerlendirme değildir (Aydın, 2007). Tayeb (1994: 429), kültürel değerlerin ve davranışların birbirinden farklılık gösterebileceğini ve hatta aynı ülkede, aynı sınırlar altında bulunan grupların kültürlerinin de birbirinden farklı olabileceğini ifade etmiştir. Normal bir toplumda ne olup bittiğinin öğrenilebilmesi için; toplumsal grupların kendi turist bakışlarını nasıl oluşturdukları üzerinde düşünmek gerektiğini vurgulayan Urry 
(2009), aynı zamanda kültürlerarası turist tutumlarının incelenmesinin önemini de belirtmiştir. Genellikle klasik sosyal psikolojik kuramlar; gruplararası ilişkilerdeki, grupların birbirlerine karşı olan tutumlarını belirlerken; "tehdit" ve "rekabet"in önemli rolünü vurgulamaktadır. Gruplararası ilişkilerde, tehdit çeşitli şekillerde algılanabilmekte ve yorumlanabilmektedir. Tehditler, sosyal, ekonomik veya politik düzeyde olabilir ve genellikle sınırlı kaynaklar üzerinde rekabet olanağı içerebilmektedir (Ward ve Berno, 2011).

Genel olarak bütünleşik tehdit teorisi, gruplararası temas ve gruplararası ilişkilerin değişmesinin yol açtığı koşullara odaklanmaktadır. Pettigrew (1998) ve Stephan (2000) tarafından tutum ve davranışlar üzerinde etkisi olan tehdit algılanmaları üzerinde durulmuştur. Bu tehditler, bir grubun eylemlerine ya da inançlarına karşı algılanabilmektedir. Bireyler hedeflerine ulaşmak için veya bir grup olarak yaşamlarını sürdürebilmek için ihtiyaç duydukları kaynakların, başkaları tarafından kullanılmasıyla, kendilerini tehdit altında hissedebilmektedirler. Söz konusu kaynaklar, güç, bilgi veya para gibi soyut ya da somut şekilde olabilmektedir. Kaynakların kıt olmasıyla ve kaynak eksikliği nedeniyle, gruplar kendi kimliklerini korumak için ya da hedeflerine ulaşmak için, kendilerini tehdit altında hissedip rekabet ederek diğer gruba karşı olumsuz tutum geliştirmektedirler.

Stephan ve Renfro (2002), gruplararası tehdit öncülerinin, gruplararası temas, grup içi kimlik ve statü eşitsizlikleri gibi faktörlere bağlı olduğunu belirlemişlerdir. Bütünleşik tehdit teorisi, cinsiyet, ırk, cinsel yönelim, ulusal köken ve özürlülük durumu da dahil olmak üzere, tüm diş gruplara karşı bireylerin önyargılarının boyutlarını ve tutumlarını belirlemek için tasarlanmıştır (Stephan vd., 2000). Gruplararası tehditler insanların algılamalarını, duygularını ve davranışlarını etkileyebileceği için çatışmalara zemin hazırlayabilmektedir. Tehdit değerlendirmesi, gruplar arasında korku, öfke, taciz, kızgınlık, gücenme, hayal kırıklığı, küçümseme ve güvensizlik gibi olumsuz duyguları da uyandırabilmektedir. Ayrıca, tehdit algılaması grup dışı üyelere karşı duygusal empatiyi de azaltabilmektedir ve tehdidin gerçek olup olmamasına bakılmaksızın, tehdit şekillerinin algılanması da önyargıya neden olabilmektedir (Avcıkurt, 2015). Bireylerin önyargılarının boyutlarını ve tutumlarını belirlemek amacıyla tasarlanan Bütünleşik Tehdit Teorisi Modeli, Şekil 1'de yer almaktadır.

\section{Şekil 1. Bütünleșik Tehdit Teorisi Modeli}

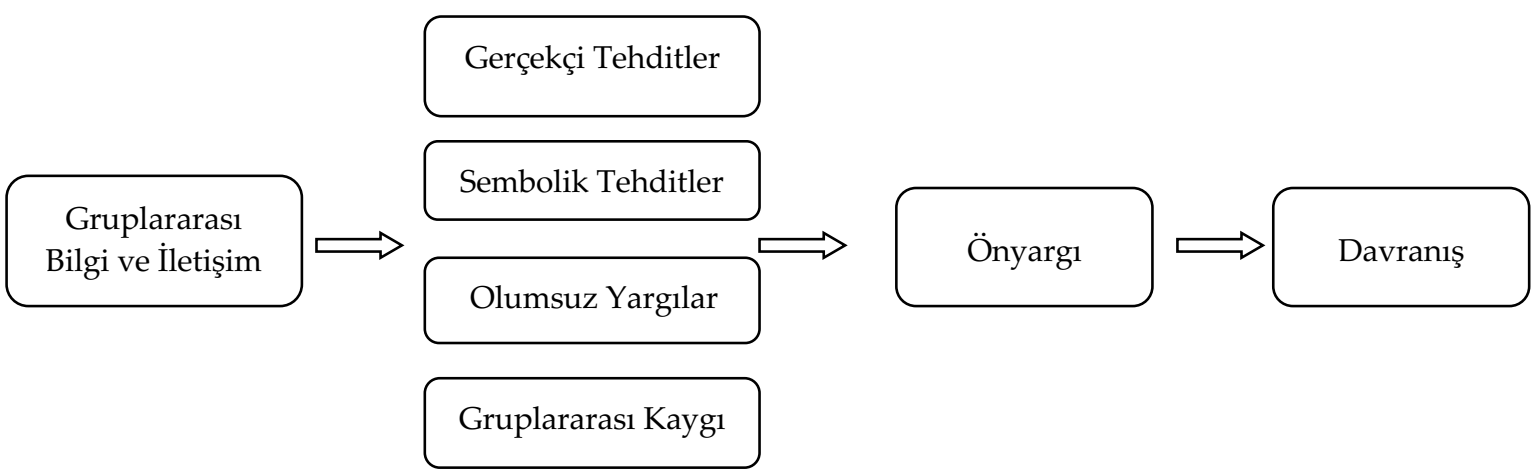

Kaynak: Redmond, 2013.

Şekil 1'de yer alan bilgiler doğrultusunda, bütünleşik tehdit teorisi, dört temel tehdit olduğunu varsaymaktadır (Stephan ve Stephan, 1996; Stephan vd., 2000; Gonzales vd., 2008; Ward ve Berno, 2011; Redmond, 2013). Bunlar; gerçekçi tehditler, sembolik tehditler, olumsuz yargılar ve gruplararası kaygidır.

Gerçekçi tehditler, bir grubun ve üyelerinin fiziksel ve maddi refahına karşı algılanan tehditleri içermektedir (Stephan vd., 1999; Stephan vd., 2000). Gerçekçi tehditler, ekonomik, fiziksel ve siyasi anlamda da kavramsallaştırılabilmektedir. Gruplar ve negatif grup reaksiyonları 
arasındaki çatışmalar genellikle, kökenlerin çıkarların çatışması olarak da ortaya çıkabilmektedir. Burada temel konu, kıt kaynaklar üzerinde algılanan bir rekabettir. Bu tür kaynaklar, grup içi çıkarlarını korumak için, bireylerde olumsuz tutum ve ayrımcılık gibi davranışların ortaya çıkmasına neden olmaktadır (Gonzales vd., 2008).

Sembolik tehditler ise; farklı kültürlerden kaynaklanan, değerler, normlar, inançlar ve tutumlar ile ilişkili olan ve bir grubun dünya görüşüne karşı olan tehditleri kapsamaktadır (Gonzales vd., 2008; Ward ve Berno, 2011). Farklı değer ve inançlara sahip olan gruplar, kendi dünya görüşünü benimsemeyen gruplara karşı düşmanlık besleyebilmektedirler ve bu da karşı grup tarafından tehdit olarak algılanabilmektedir. Sembolik tehdit anlayışı, sembolik ırkçılık anlayışıyla da yakından ilişkilidir (Stephan vd., 1999).

Olumsuz yargılar genel olarak, etnik ve ulusal kalıplaşmış tartışmalardan ortaya çıksa da önyargılardan kaynaklanmaktadır (Ward ve Berno, 2011). Bireylerin, bir dış grup hakkındaki olumsuz yargıları; şiddetli düşmanlık, öfke ve kibirli davranmak olarak algılanarak, karşı grup üyelerinin negatif davranması beklenmektedir ve tehdit algılanması meydana gelmektedir (Gonzales vd., 2008). Etkileşim halinde bulunulan grup ile ilgili kalıp yargılara dayanarak davranan bireyler, kendilerini tehdit altında hissedebilmektedirler ve gerçek grup ile uyuşmayan bilgilere maruz kalarak hareket ettiklerinden dolayı gruplararası karşılaşma boyutları olumsuz olarak sonuçlanabilmektedir (Paolini vd., 2004).

Bütünleşik tehdit teorisini oluşturan son tehdit unsuru, gruplararası kaygı ise; bireylerin reddedilmekten korkması ya da insanlar arası etkileşimler ile ilgili olarak tehdit hissetmesi, grubun üyeleri ile etkin bir etkileşim halinde bireyin kendisini yetersizlik olarak görmesi ve sonucunda alay edilmek veya utanmaktan kaynaklanan davranışları içermektedir (Ward ve Berno, 2011). Gruplararası kaygı evresinde, söz konusu grupların daha önceden düşmanlık ilişkisi varsa, kaygının özellikle yüksek olacağı belirtilmektedir (Stephan vd., 1999). Örneğin; Stephan, Ybarra ve Morrison (2007), yapmış oldukları araştırmada; İsrailliler ve Araplar arasındaki çatışmanın, bütünleşik tehdit teorisine bir örnek olduğunu vurgulamışlardır. Her iki grupta da ekonomi, güç, din, dil, kültürel farklılık ve farklı dünya görüşleri olduğundan dolayı hem gerçekçi hem de sembolik tehditlerin var olduğunu ifade etmişlerdir. Her bir grup, farklı kültürel değerler ve yaşam biçimlerine sahip oldukları için birbirlerini temel bir tehdit olarak algılamaktadırlar. Bütünleşik tehdit teorisi, tehdit öncülleri olarak, algılanan gruplararası çatışmayı, grup içi kimlik ve statü farklılıkları ya da eşitsizliği ile bilgi ve iletişim eksikliklerinin varlığına işaret etmektedir. Ayrıca olumsuz temas deneyimleri de tehditlere dâhil edilebilmektedir. Çeşitli gruplara karşı geliştirilen olumsuz tutumlar negatif iletişim deneyimleri ile sonuçlandığından, daha fazla gruplararası iletişimin varlığı; algılanan gruplararası çatışmayı, algılanan durum farklılıklarını ve tehditlerin çoğunun kısmen de olsa azalmasina aracilik etmektedir (Aberson ve Gaffney, 2008).

Genel olarak ifade etmek gerekirse; gruplararası tehditler insanların birbirlerini algılamalarını, duygularını ve davranışlarını etkileyebileceği için aynı zamanda çatışmalara da zemin hazırlayabilmektedir. Tehdit değerlendirmeleri, gruplar arasında korku, öfke, taciz, kızgınlık, gücenme, hayal kırıklığı, küçümseme ve güvensizlik gibi olumsuz duyguları uyandırabilmekte ve ayrıca, tehdit algılamaları grup dışı üyelere karşı duygusal empatiyi de azaltabilmektedir. Algılanan tehditlerin gerçek olup olmamasına bakılmaksızın da tehdit şekillerinin algılanması önyargıya neden olabilmektedir (Avcıkurt, 2015). Gruplar arasındaki önyargı oluşumunu önlemek için, 1950'li y1llarda bir hipotez olarak ortaya atılan temas hipotezine göre; birbirini olumsuz yönlü değerlendiren grup üyeleri arasında olumlu etkileşimler aracilığıyla temas sağlamak da önyargının azalmasına neden olabilmektedir. Bu nedenle birbirini olumsuz olarak algılayan ve değerlendiren grupların üyeleri arasında etkileşim sağlanırsa, kalıp yargıların varlığ1 ve nedenleri sorgulanmaya başlayabilmektedir. Söz konusu hipoteze göre; birbirine 
önyargılı olan grupların tarafsız bir ortamda bir araya gelmeleri sonucunda olumlu ilişkiler geliştirilebileceğine ve birbirlerine karşı olan bakış açılarının değiştirilebileceğine inanılmaktadır (Pettigrew, 1998; Çuhadar Gürkaynak, 2012).

Özellikle turizmde kültürel farklılıkların ve ortaya çıkan farklı davranışların artmasıyla birlikte, kültürel farklılıkların, yerel kültürel köklerin ve mirasların anlaşılması, turistlerin kimliklerine ve değerlerine gösterilen saygı, daha fazla turist çekebilmek için belirlenen bir hedef konumundadır (Reisinger ve Crotts, 2010). Farklı kültürel geçmişlere sahip çeşitli ülkelerden gelen turistlerin, farklı davranışlarını anlamak; daha fazla uluslararası turist çekebilmek için pazarlama stratejilerinin tasarlanmasında, ülkelerin turizm otoriteleri için çok önemlidir (Hsu, Woodside ve Marshall, 2013). Aynı zamanda, turistlerin seyahatleri esnasında nasıl hissettikleri hakkında detaylı bilgi sahibi olunması, turizmde hizmet sağlayıcılar açısından da önem arz etmektedir (Nawijn vd, 2012).

\section{YÖNTEM}

Bu araştırmanın amacl; Doğu Karadeniz Bölgesi'ne gelen Arap turistlerin, "Bütünleşik Tehdit Teorisi" çerçevesinde, "gerçekçi tehdit", "sembolik tehdit", "olumsuz yargılar" ve "gruplararası kaygı" başlıkları altında, Türklere önyargılı yaklaşıp yaklaşmama durumlarının araştırılmasıdır. Ayrıca Arap turistlerin, Doğu Karadeniz Bölgesini ziyaretleri süresince algıladıkları bütünleşik tehditlerin, Türklere karşı önyargılı davranmalarına neden olabileceği varsayımından hareketle belirlenen temel araştırma hipotezleri aşağıdaki gibidir:

H1: Arap turistlerin Doğu Karadeniz Bölgesi'ni ziyaretleri süresince algıladıkları gerçekçi tehditler ile Türklere karşı önyargılı davranmaları arasında anlamlı bir ilişki vardır.

H2: Arap turistlerin Doğu Karadeniz Bölgesi'ni ziyaretleri süresince algıladıkları sembolik tehditler ile Türklere karşı önyargılı davranmaları arasında anlamlı bir ilişki vardir.

H3: Arap turistlerin Doğu Karadeniz Bölgesi'ni ziyaretleri süresince algıladıkları olumsuz yargılar ile Türklere karşı önyargılı davranmaları arasında anlamlı bir ilişki vardir.

H4: Arap turistlerin Doğu Karadeniz Bölgesi'ni ziyaretleri süresince algıladıkları gruplararası kaygılar ile Türklere karşı önyargılı davranmaları arasında anlamlı bir ilişki vardir.

H5: Arap turistlerin Doğu Karadeniz Bölgesi'ni ziyaretleri süresince algıladıkları bütünleşik tehditler ile Türklere karşı önyargılı davranmaları arasında anlamlı bir ilişki vardır.

$\mathrm{Bu}$ araştırmanın evrenini, Türkiye'ye gelen Arap turistler oluşturmaktadır. 2018 yılında Türkiye'ye gelmiş olan Arap turist sayısı 4.784.622'dur (yigm.ktb.gov.tr, 2019). Araştırmada, belirlenen evrenin tamamına ulaşılmasının mümkün olamayacağından hareketle, araştırmanın evrenini oluşturan turistlerden örneklem seçilmesine ve araştırmanın bu örneklem üzerinde gerçekleştirilmesine karar verilmiştir. Bu doğrultuda; Arap turistler tarafından Türkiye genelinde İstanbul hariç en çok tercih edilen üç destinasyondan biri olan Doğu Karadeniz Bölgesi, araştırmanın örneklemini oluşturmaktadır. Doğu Karadeniz Bölgesi; İstatistiki Bölge Birimleri Sınıflandırması (IBSS) dikkate alınarak sınırlandırılmıştır. Buna göre, çalışmaya konu olan Doğu Karadeniz Bölgesi'nde; Artvin, Giresun, Gümüşhane, Ordu, Rize ve Trabzon illeri yer almaktadır. Bu durumda, Doğu Karadeniz Bölgesi'ne sadece Arap ülkelerinden gelen turist sayısına yönelik istatistiki bir veri olmamasından dolayı, evren büyüklügüne karşılık örneklem 
büyüklügü tablosuna göre; evren büyüklüğü 100.000 ise gereken örneklem sayısı en fazla 384 (Ural ve Kılıç, 2013: 47) dikkate alınmış ve yeterli örneklem büyüklügüne ulaşılmıştır.

Anket uygulaması, Arap turistlerin söz konusu bölgeyi en çok ziyaret ettikleri tarih aralığı olan Nisan-Haziran (2019) ayları arasında gerçekleştirilmiştir. Bu süre içerisinde 450 adet anket, Artvin (Borçka/Karagöl), Giresun (Kümbet Yaylası), Gümüşhane (Karaca Mağarası), Ordu (Boztepe), Trabzon (Uzungöl, Zigana) ve Rize (Ayder Yaylası) illerinde, araştırmacilar tarafından Arap turistlere doğrudan dağıtılıp toplanmış ve 410'undan geri dönüş alınmıştır. Dolayısıyla araştırmada 410 anket değerlendirmeye alınmıştır.

$\mathrm{Bu}$ araştırmada, araştırma değişkenlerini ölçmeye yönelik hazırlanan ifadelerin yer aldığı, Arapça ve İngilizce dillerine çevrilen anket formu, veri toplama aracı olarak kullanılmıştır. Bu aşamada Saatcı (2016) tarafından güvenilirliği kanıtlanmış Bütünleşik Tehdit Teorisi ölçeğinden faydalanılmıştır. Araştırma anketi iki bölümden oluşmaktadır. Birinci bölümde, turistlerin demografik bilgileri ve turistik özelliklerine ilişkin 12 soru bulunmaktadır. Anketin ikinci kısmında ise turistlerin bütünleşik tehdit teorisine ait alt tehdit ölçeklerine ve gruplararası önyargıya ilişkin düşüncelerini tespit edebilmek amacıyla sunulan ifadeler yer almaktadır.

Anket uygulaması gerçekleştirildikten sonra, değerlendirilmeye alınan verilerden ankete katılan Arap turistlerin demografik özellikleri yüzde ve frekans yöntemi kullanılarak analiz edilmiştir. Ayrıca Türklere yönelik önyargıların değerlendirilmesine ilişkin ifadelerin aritmetik ortalama ve standart sapma analizleri yapılmıştır. Araştırmanın hipotezlerini test edebilmek için ise; çeşitli parametrik olmayan testlerden yararlanılmıştır.

Güvenirlik analizi, araştırma yapılacak konuda, seçilen örneklemi oluşturan birimler üzerinden veri toplamak amacı ile geliştirilen ölçme aracını oluşturan ifadelerin, kendi aralarında tutarlı olup olmadıklarını test etmek amacı ile kullanılmaktadır (Ural ve Kılıç, 2013: 280). Bu araştırmada, araştırma ölçeğindeki 45 maddenin güvenilirliği içsel tutarlılık (homojenlik) yöntemine dayalı olarak "Cronbach's Alpha" ölçütü kullanılarak hesaplanmıştır. "Bütünleşik Tehdit Teorisi Ölçek Güvenirlik Analizi" sonucuna göre; Cronbach's Alpha 0,932 olarak tespit edilmiştir. Bu sonuca göre, Bütünleşik Tehdit Teorisi Ölçeği yüksek derecede güvenilirdir ve alfa katsayısı değeri sosyal bilim araştırmaları için kabul edilebilir düzeyin üzerinde gerçekleşmektedir.

$\mathrm{Bu}$ araştırmada ayrıca verilere ilişkin normallik testi de yapılmıştır. Bu kapsamda normallik varsayımı araştırılmış ve hem Kolmogorov-Smirnov hem de Shapiro-Wilk testi ile analiz edilmiştir. Analiz sonunda araştırma verilerinin normal dağılıma sahip olmadığı tespit edilmiştir. Dolayısıyla analizler parametrik olmayan testler aracılığı ile gerçekleştirilmiştir.

\section{BULGULAR VE YORUM}

Araştırmanın örneklem grubunda yer alan Arap turistlerin tanımlayıcı özelliklerine ilişkin dağılım Tablo 1'de sunulmuştur.

Tablo 1'e göre; araştırmaya katılan Arap turistlerden 216 kişi (\%52,7) erkek ve 194 kişi (\%47,3) kadındır. Katılımcılardan 257 kişi $(\% 62,7)$ evlidir. Yaş grubu dağılımlarına bakıldığında, 23-32 yaş grubu olanlar 168 kişi (\%41) ile ağırlıklı bir yüzdeye sahiptir. Eğitim düzeyleri ile ilgili dağılım incelendiğinde ise; üniversite mezunlarının 283 kişi (\%69) ile en yüksek yüzdeye sahip olduğu görülmektedir. Meslek dağılımı açısından bakıldığında; işveren (tüccar) olanların 168 kişi (\%41) ile ağırlıklı bir yüzdeye sahip olduğu görülmektedir. Son olarak gelir seviyesine göre yapılan incelemeye bakıldığında, Arap turistlerden 222 kişinin $(\% 54,1)$ orta düzeyde gelire sahip olduklarını belirttikleri görülmektedir. 
Tablo 1. Katılımcılara Ait Tanımlayıcı Bilgiler

\begin{tabular}{|c|c|c|c|c|c|}
\hline Değişkenler & $\mathbf{N}$ & $\%$ & Değişkenler & $\mathbf{N}$ & $\%$ \\
\hline \multicolumn{3}{|l|}{ Cinsiyet } & \multicolumn{3}{|l|}{ Meslek } \\
\hline Kadın & 194 & 47,3 & Memur, İşçi (ücretli bir işte çalışıyorum) & 106 & 25,9 \\
\hline Erkek & 216 & 52,7 & Serbest (Avukat, Eczacl, Mühendis vb.) & 77 & 18,7 \\
\hline Toplam & 410 & 100,0 & İşveren (Tüccar) & 168 & 41,0 \\
\hline \multicolumn{3}{|l|}{ Medeni Durum } & Emekli & 19 & 4,6 \\
\hline Evli & 257 & 62,7 & İşsiz & 7 & 1,7 \\
\hline Bekâr & 153 & 37,3 & Öğrenci & 24 & 5,9 \\
\hline Toplam & 410 & 100,0 & Ev Hanımı & 9 & 2,2 \\
\hline \multicolumn{3}{|l|}{ Yaş } & Toplam & 410 & 100,0 \\
\hline 22 yaş ve altı & 118 & 28,8 & & & \\
\hline 23-32 yaş arası & 168 & 41,0 & \multicolumn{3}{|l|}{ Ortalama Aylık Gelir } \\
\hline $33-42$ yaş arası & 57 & 13,9 & Çok düşük & 82 & 20,0 \\
\hline $43-52$ yaş arası & 29 & 7,1 & Düşük & 59 & 14,4 \\
\hline 53 yaş ve + & 38 & 9,3 & Orta & 222 & 54,1 \\
\hline Toplam & 410 & 100,0 & Yüksek & 45 & 11,0 \\
\hline \multicolumn{3}{|l|}{ Eğitim Durumu } & Çok yüksek & 2 & 0,5 \\
\hline İlköğretim & 5 & 1,2 & Toplam & 410 & 100,0 \\
\hline Ortaöğretim & 59 & 14,4 & & & \\
\hline Üniversite & 283 & 69,0 & & & \\
\hline Lisansüstü & 63 & 15,4 & & & \\
\hline Toplam & 410 & 100,0 & & & \\
\hline
\end{tabular}

Bu araştırmaya katılan Arap turistlere yöneltilen "daha önce Türkiye'de bulundunuz mu? ve ne amaçla bulundunuz?" sorularına ilişkin yapılan analiz Tablo 2' de yer almaktadır.

Tablo 2. Arap Turistlerin Daha Önceden Türkiye'de Bulunma Durumları ve Türkiye'de Bulunma Amaçları

\begin{tabular}{|c|c|c|c|}
\hline & & $\mathbf{N}$ & $\%$ \\
\hline \multirow{7}{*}{$\begin{array}{l}\text { Daha Önceden Türkiye'de } \\
\text { Bulunma Durumu }\end{array}$} & Daha önce Türkiye'de bulunmayan & 188 & 45,9 \\
\hline & $1 \mathrm{kez}$ & 102 & 24,9 \\
\hline & $2 \mathrm{kez}$ & 46 & 11,2 \\
\hline & $3 \mathrm{kez}$ & 16 & 3,9 \\
\hline & $4 \mathrm{kez}$ & 2 & 0,5 \\
\hline & $5 \mathrm{kez}$ ve üzeri & 56 & 13,7 \\
\hline & Toplam & 410 & 100,0 \\
\hline \multirow{7}{*}{ Türkiye'de Bulunma Amacı } & Daha önce Türkiye'de bulunmayan & 188 & 45,9 \\
\hline & İş & 34 & 8,3 \\
\hline & Eğitim & 51 & 12,4 \\
\hline & Tatil & 131 & 32,0 \\
\hline & Sağlık & 3 & 0,7 \\
\hline & Diğer & 3 & 0,7 \\
\hline & Toplam & 410 & 100,0 \\
\hline
\end{tabular}

Tablo 2'ye göre; araştırmaya katılan Arap turistlerden 188 kişi $(\% 45,9)$ daha önceden Türkiye'de bulunmamışken, 222 kişi $(\% 54,1)$ Türkiye'de bulunmuştur. 1 kez Türkiye'de bulunanların sayısı ise 102 kişidir $(\% 24,9)$ ve daha çok tatil amacıyla (\%32) Türkiye'de bulunmuşlardır. Diğer katılımcıların Türkiye'de bulunma amaçları da sırasıyla; eğitim, iş ve sağlıktır. Araştırmaya 
katılan Arap turistlere yöneltilen "tatile kiminle geldiniz?" sorusuna ilişkin yapılan analiz Tablo 3'te yer almaktadır.

Tablo 3. Arap Turistlerin Tatile Katılma Durumu

\begin{tabular}{lcc}
\hline Tatile Katılma Durumu & N & \% \\
\hline Bireysel & 46 & 11,2 \\
Arkadaş grubu & 82 & 20,0 \\
Aile & 179 & 43,6 \\
Eş & 103 & 25,2 \\
Toplam & $\mathbf{4 1 0}$ & $\mathbf{1 0 0 , 0}$ \\
\hline
\end{tabular}

Tablo 3'e göre; Arap turistlerin büyük çoğunluğu ailesiyle $(\% 43,6)$ ve eşiyle $(\% 25,2)$ beraber tatile katıldıklarını belirtmişlerdir. Tatile arkadaş grubu ile birlikte $(\% 20,0)$ ve bireysel olarak $(\% 11,2)$ katılanların sayısı ise nispeten daha azdır. Araştırmaya katılan Arap turistlerin Türkiye'de bulunma sürelerine ilişkin yapılan analiz Tablo 4'te verilmektedir.

Tablo 4. Arap Turistlerin Türkiye'de Bulunma Süreleri

\begin{tabular}{lcc}
\hline Türkiye'de Bulunulan Gün Sayısı & $\mathbf{N}$ & $\mathbf{\%}$ \\
\hline 1-3 gün & 41 & 10,0 \\
4-6 gün & 41 & 10,0 \\
7-9 gün & 128 & 31,2 \\
10 gün ve üzeri & 200 & 48,8 \\
Toplam & $\mathbf{4 1 0}$ & $\mathbf{1 0 0 , 0}$ \\
\hline
\end{tabular}

Tablo 4'te yer alan verilere göre, Arap turistlerin Türkiye'de bulunma süreleri incelendiğinde; 200 kişi $(\% 48,8) 10$ günden fazla konaklama yaptığını belirtmiştir. Türkiye'de 1-3 gün ile 4-6 gün arasında bulunan turistlerin sayıları eşit $(n=41)$ iken, 7-9 gün arasında bulunanların sayısı da $(n=128)$ genel sıralamada ikinci sırada yer almaktadır. Araştırmaya katılan Arap turistlerin Türkler ile iletişim kurmaktan çekinip çekinmeme durumlarına ilişkin yapılan analiz Tablo 5 'te sunulmaktadır.

Tablo 5. Arap Turistlerin Türklerle İletişim Kurmaktan Çekinme Durumları

\begin{tabular}{lcc}
\hline Türklerle İletişim Kurmaktan Çekinme Durumları & N & \% \\
Evet & 46 & 11,2 \\
Hayır & 364 & 88,8 \\
Toplam & $\mathbf{4 1 0}$ & $\mathbf{1 0 0 , 0}$ \\
\hline
\end{tabular}

Tablo 5'e göre; Arap turistlerden 364 kişi yüksek bir oran ile $(\% 88,8)$ Türkler ile iletişim kurmaktan çekinmediğini ifade ederken 46 kişi de iletişim kurmaktan çekindiğini belirtmiştir. Araştırmaya katılan Arap turistlerin, Türklerin birbirlerine benzer tutuma sahip olup olmama düşüncesine ilişkin yapılan analiz Tablo 6 'da sunulmaktadır. 
Tablo 6. Türklerin Birbirine Benzer Tutuma Sahip Olma Durumları

\begin{tabular}{lcc}
\hline Türklerin Birbirine Benzer Tutuma Sahip Olma Durumları & $\mathbf{N}$ & $\mathbf{\%}$ \\
\hline Evet & 49 & 12,0 \\
Hayır & 361 & 88,0 \\
Toplam & $\mathbf{4 1 0}$ & $\mathbf{1 0 0 , 0}$ \\
\hline
\end{tabular}

Tablo 6'ya göre; Arap turistlerden büyük çoğunluğu (\%88), Türklerin birbirine benzer tutuma sahip olmadığını düşündüklerini ifade ederken katılımcıların düşük bir oranı (\%12) da Türklerin birbirlerine benzer tutuma sahip olduğunu düşündüklerini belirtmişlerdir.

$\mathrm{Bu}$ araştırmada Arap turistlerin, "Bütünleşik Tehdit Teorisi" altında bulunan "gerçekçi tehditler", "sembolik tehditler", "olumsuz yargılar" ve "gruplararası kaygı" alt başlıklarına ilişkin görüşleri ile "gruplararası önyargı" yaşayıp yaşamadıklarının araştırılmasını amaçlayan önermeler, genel olarak beş bölüm halinde sunulmuştur. Öncelikle Bütünleşik Tehdit Teorisi'nin her bir aşaması tek tek ele alınmış, ardından da turistlerin gruplararası önyargı ile ilgili görüşleri ortaya çıkarılmak istenmiştir. Bu bağlamda söz konusu önermeler Tablo 7 'de verilmiştir.

Tablo 7'de yer alan bulgulara göre, "Bütünleşik Tehdit Teorisi" çerçevesinde tehdit algılamalarının ölçülmesine yönelik olarak hazırlanan ifadelerde genel olarak Arap turistlerin en fazla katılım gösterdikleri ifadeler; "Türkler geleneklerine bizden daha fazla değer verirler" $(x=3,38)$ ile "Türkler ile birbirimizden farklı aile değerlerimiz vardır" $(x=3,09)$ şeklindedir.

"Bütünleşik Tehdit Teorisi" nin ilk bölümü olan "gerçekçi tehditler" kategorisinde; Arap turistlerin en fazla katılım gösterdiği ifade, "Türklere ortak kullanım alanlarında ayrımcılık yapılıyor" $(x=2,71)$ ifadesi iken; en düşük katılıma sahip ifade, "Türklere olması gerekenden daha fazla hoşgörülü davranılıyor" $(x=1,90)$ şeklindedir.

Bütünleşik Tehdit Teorisi modelinin ikinci kategorisi olan "sembolik tehditler" kategorisinde; "Türkler geleneklerine bizden daha fazla değer verirler" $(x=3,38)$ ifadesi, Arap turistler için en fazla katılım gerçekleşen ifadedir. Arap turistlerin en az katılım gösterdikleri ifade ise "Türklerin yaşam tarzları bulunduğum yerin genel ortamını olumsuz etkilemektedir" $(x=1,70)$ şeklindedir.

Bütünleşik Tehdit Teorisi modelinin üçüncü kategorisi olan "olumsuz yargılar" kategorisinde, Arap turistlerin görüşleri olarak ortaya çlkan; "Türkler gürültülüdür" $(x=2,38)$ ve "Türkler önyargılıdır" $(x=2,25)$ ifadelerine katılım en yüksek düzeydedir. Öte yandan; "Türkler korkaktır" $(x=1,68)$, "Türkler soğuktur" $(x=1,72)$, "Türkler bencildir" $(x=1,76)$ ve "Türkler tembeldir" $(x=1,77)$ ifadeleri daha az katılım düzeyiyle ortaya çıkmaktadır.

Bütünleşik Tehdit Teorisi modelinin son tehdit unsuru olan "gruplar arası kayg1" kategorisinde, Arap turistlerin ifadelere katılım düzeyleri incelendiğinde; "Türkler tarafindan eleştirildim" $(x=1,71)$ ifadesi yüksek katılım payı ile ön plana çıkarken; "Türkler tarafindan fiziksel zarara uğradım" $(x=1,26)$, "Türkler tarafindan küçük düşürüldüm" $(x=1,41)$, "Türkler tarafindan tacize uğradım" $(x=1,42)$ ifadeleri de düşük katılım paylarına sahiptir.

Arap turistlerin gruplar arası önyargı ile ilgili görüşlerini ortaya çıkarmaya yönelik sunulan ifadelerin yapılan değişken analizi sonucuna göre; Arap turistlerin en fazla katılım gösterdikleri ifade "Türkler ile sorunlu bir geçmişimiz vardır" $(x=2,37)$ ifadesidir. Arap turistlerin en düşük katılım gösterdikleri ifade ise; "Türkler ile bulunduğumuz ortamlarda genellikle sorun yaşanmaktadır" $(x=1,76)$ ifadesidir. 
Tablo 7. Bütünleşik Tehdit Teorisi Ölçek Maddelerinin Analizi

\begin{tabular}{|c|}
\hline IFADELER \\
\hline GERÇEKÇİ TEHDITLER \\
\hline 1. Türkler dünyada çok fazla iktidar mevkiine sahiptir. \\
\hline 2. Türkler dünya siyasetine çok fazla hâkimdir. \\
\hline 3. Türklere ortak kullanım alanlarında ayrımcılık yapılıyor. \\
\hline 4. Türklerin ekonomik gücü çok fazladır. \\
\hline 5. Türklerin bulunmadığ 1 alanlarda kendimi güvende hissediyorum. \\
\hline 6. Türklere olması gerekenden daha fazla hoşgörülü davranılıyor. \\
\hline 7. Türklerin bulundukları ortamlarda suç oranları artar. \\
\hline $\begin{array}{l}\text { 8. Türkler, bulunduğumuz ortamlardaki sosyal refah seviyesinin azalmasına neden } \\
\text { oluyorlar. }\end{array}$ \\
\hline 9. Türkler ortak kullanım alanlarında öncelikli olmak isterler. \\
\hline
\end{tabular}

SEMBOLIK TEHDİTLER

1. Türkler ile çok farklı değer yargılarına sahibim.

2. Türkler benim dünya görüşüme saygı göstermekten çekinirler.

3. Türkler ile birbirimizden farklı aile değerlerimiz vardır.

4. Türkler geleneklerine bizden daha fazla değer verirler.

5. Türkler bize göre ahlaki yönden kendilerini bizden üstün sayıyorlar.

6. Türkler bize saygısız davranıyorlar.

7. Türklerin aile ilişkileri zayıftır.

8. Türklerin çocuk yetiştirme tarzları zayıftır.

9. Türklerin kültürel değerleri bulunduğum ortamın atmosferine zarar vermektedir.

10. Türklerin yaşam tarzları bulunduğum yerin genel ortamını olumsuz etkilemektedir.

\section{OLUMSUZ YARGILAR}

1. Türkler bencildir.

2. Türkler hilekârdır.

3. Türkler soğuktur.

4. Türkler önyargılıdır.

5. Türkler kabadır.

6. Türkler korkaktır.

7. Türkler tembeldir.

8. Türkler yalancıdır.

9. Türkler gürültülüdür.

10. Türkler laubalidir.

\section{GRUPLARARASI KAYGI}

1. Türkler tarafından aşağılandım.

2. Türkler tarafından hakarete uğradım.

3. Türkler benimle dalga geçti.

4. Türkler tarafından dışlandım.

5. Türkler tarafından tacize uğradım.

6. Türkler tarafından küçük düşürüldüm.

7. Türkler tarafından eleştirildim.

8. Türkler tarafından tehdit edildim.

9. Türkler tarafından sözlü tacize uğradım.

10. Türkler tarafından fiziksel zarara uğradım.

\section{GRUPLARARASI ÖNYARGI}

1. Türkler ile olan ilişkilerimiz her zaman önyargı ile değerlendirilmiştir.

2. Türkler ile sorunlu bir geçmişimiz vardır.

3. Her zaman görünür olmasa da Türkler ile aramızda süregelen bir çatışma vardır.

4. Türkler ile her zaman geçinmekte zorlanmışızdır.

5. Türkler ile bulunduğumuz ortamlarda genellikle sorun yaşanmaktadır.
A.O.

2,69

2,65

2,71

2,68

2,01

1,90

1,86

2,27

2,46

2,13

1,168

s.s.

0,848

0,987

0,937

1,131

1,050

1,089

1,024

1,057

1,023

$2,45 \quad 1,008$

$3,09 \quad 1,219$

$3,38 \quad 1,177$

$2,62 \quad 1,090$

$1,88 \quad 0,974$

$1,76 \quad 0,995$

$2,03 \quad 1,010$

$1,74 \quad 0,903$

$\mathbf{1 , 7 0} \quad 0,912$

\begin{tabular}{l|l}
$\mathbf{1 , 7 6}$ & 0,938
\end{tabular}

$1,88 \quad 0,970$

$\mathbf{1 , 7 2} 0,908$

$\mathbf{2 , 2 5} 1,134$

$\mathbf{1 , 6 8} 0,902$

$1,77 \quad 0,994$

$1,95 \quad 1,082$

$2,38 \quad 1,267$

\begin{tabular}{l|l}
1,98 & 1,041
\end{tabular}

\begin{tabular}{l|l}
1,50 & 0,874
\end{tabular}

$1,55 \quad 0,937$

$1,54 \quad 0,935$

$1,50 \quad 0,854$

$\mathbf{1 , 4 2} \quad 0,775$

$\mathbf{1 , 4 1} 0,826$

$\mathbf{1 , 7 1} 1,108$

$1,47 \quad 0,909$

$1,59 \quad 1,731$

$\mathbf{1 , 2 6} 0,643$

\begin{tabular}{l|l}
2,35 & 1,131
\end{tabular}

$2,37 \quad 1,203$

$1,99 \quad 1,055$

$1,81 \quad 0,929$

$\mathbf{1 , 7 6} 0,923$

\begin{tabular}{l|l}
2,93 & 1,741
\end{tabular}

$1,85 \quad 0,931$ 
$\mathrm{Bu}$ araştırmanın beş temel hipotezinin sınanmasına ilişkin olarak korelasyon analizi yapılmıştır. Analiz sonuçları Tablo 8'de verilmektedir.

Tablo 8. Korelasyon Analizi ve Hipotez Sonuçları

\begin{tabular}{|c|c|c|c|}
\hline SPEARMAN'S RHO & & Gruplararası Önyargı & Hipotez Sonuçları \\
\hline \multirow{2}{*}{ Gerçekçi Tehditler (H1) } & $\mathbf{r}$ & 0,337 & \multirow{2}{*}{ Kabul } \\
\hline & $\mathrm{p}$ & 0,000 & \\
\hline \multirow{2}{*}{ Sembolik Tehditler (H2) } & $\mathbf{r}$ & 0,495 & \multirow{2}{*}{ Kabul } \\
\hline & $\mathrm{p}$ & 0,000 & \\
\hline \multirow{2}{*}{ Olumsuz Yargılar (H3) } & $\mathbf{r}$ & 0,407 & \multirow{2}{*}{ Kabul } \\
\hline & p & 0,000 & \\
\hline \multirow{2}{*}{ Gruplararası Kaygı (H4) } & $\mathbf{r}$ & 0,328 & \multirow{2}{*}{ Kabul } \\
\hline & $\mathrm{p}$ & 0,000 & \\
\hline \multirow{2}{*}{ Bütünleşik Tehditler (H5) } & $\mathbf{r}$ & 0,492 & \multirow{2}{*}{ Kabul } \\
\hline & $\mathbf{p}$ & 0,000 & \\
\hline
\end{tabular}

Tablo 8'de yer alan bulgulara göre, temel araştırma hipotezlerinin sınanmasına ilişkin test sonuçları aşağıda açıklanmaktadır.

H1: Arap turistlerin Doğu Karadeniz Bölgesi'ni ziyaretleri süresince algıladıkları gerçekçi tehditler ile Türklere karşı önyargılı davranmaları arasında anlamlı bir ilişki vardır.

Arap turistler için; gerçekçi tehditlerin algılanması ile Türklere karşı önyargıılı davranmalarının arasında anlamlı, pozitif yönde ve orta düzeyde bir ilişki olduğu tespit edilmiştir $(\mathrm{r}=0,337$; $\mathrm{p}<0,001)$. Bu durumda Arap turistlerin Doğu Karadeniz Bölgesi'ni ziyaretleri boyunca algılamış oldukları gerçekçi tehditlerin, Türklere karşı önyargılı davranmalarına neden olduğu söylenebilmektedir. Dolayısıyla H1 kabul edilmiştir.

H2: Arap turistlerin Doğu Karadeniz Bölgesi'ni ziyaretleri süresince algıladıkları sembolik tehditler ile Türklere karşı önyargılı davranmaları arasında anlamlı bir ilişki vardır.

Arap turistler için; sembolik tehditlerin algılanması ile Türklere karşı önyargılı davranmalarının arasında anlamll, pozitif yönde ve orta düzeyde bir ilişki olduğu tespit edilmiştir ( $r=0,495$; $\mathrm{p}<0,001)$. Bir diğer ifadeyle; Arap turistlerin Doğu Karadeniz Bölgesi'ni ziyaretleri boyunca algılamış oldukları sembolik tehditlerin, Türklere karşı önyargılı davranmalarına neden olduğu söylenebilmektedir. Bu durumda H2 kabul edilmiştir.

H3: Arap turistlerin Doğu Karadeniz Bölgesi'ni ziyaretleri süresince algıladıkları olumsuz yargllar ile Türklere karşı önyargılı davranmaları arasında anlamlı bir ilişki vardır.

Arap turistler için; olumsuz yargıların algılanması ile Türklere karşı önyargılı davranmalarının arasında anlamlı, pozitif yönde ve orta düzeyde bir ilişki olduğu tespit edilmiştir $(r=0,407$; $\mathrm{p}<0,001)$. Bu durumda, Arap turistlerin Doğu Karadeniz Bölgesi'ni ziyaretleri boyunca algilamış oldukları olumsuz yargıların, Türklere karşı önyargılı davranmalarına neden olduğu söylenebilmektedir. Dolayısıyla H3 kabul edilmiştir.

H4: Arap turistlerin Doğu Karadeniz Bölgesi'ni ziyaretleri süresince algıladıkları gruplararası kaygılar ile Türklere karşı önyargılı davranmaları arasında anlamlı bir ilişki vardır.

Arap turistler için; gruplararası kaygıların algılanması ile Türklere karşı önyargılı davranmalarının arasında anlaml, pozitif yönde ve orta düzeyde bir ilişki olduğu tespit edilmiştir $(\mathrm{r}=0,328 ; \mathrm{p}<0,001)$. Bir diğer ifadeyle; Arap turistlerin Doğu Karadeniz Bölgesi'ni ziyaretleri boyunca algılamış oldukları gruplararası kaygının, Türklere karşı önyargılı davranmalarına neden olduğu söylenebilmektedir. Bu durumda H4 kabul edilmiştir. 
H5: Arap turistlerin Doğu Karadeniz Bölgesi'ni ziyaretleri süresince algzladıkları bütünleşik tehditler ile Türklere karşı önyargılı davranmaları arasında anlamlı bir ilişki vardır.

Arap turistler için; bütünleşik tehditlerin algılanması ile Türklere karşı önyargılı davranmalarının arasında anlamlı, pozitif yönde ve orta düzeyde bir ilişki olduğu tespit edilmiştir $(r=0,492 ; p<0,001)$. Yani Arap turistlerin Doğu Karadeniz Bölgesi'ni ziyaretleri boyunca algılamış oldukları bütünleşik tehditlerin, Türklere karşı önyargılı davranmalarına neden olduğu söylenebilmektedir. Bu durumda H5 kabul edilmiştir.

\section{SONUÇ VE DEĞERLENDİRME}

$\mathrm{Bu}$ araştırma ile Arap turistlerin algıladıkları tehditler doğrultusunda Türklere önyargılı olup olmama durumları ortaya çıkarılması amaçlanmıştır. Araştırma sonuçlarına göre; araştırmaya katılan Arap turistlerin büyük çoğunluğu, 23-32 yaş grubunda, üniversite mezunu, erkek, işveren, evli ve orta düzey gelire sahiptir. Arap turistler daha çok tatil amacıyla Türkiye'de bulunmuşlardır. Diğer katılımcıların Türkiye'de bulunma amaçları da sırasıyla; eğitim, iş ve sağlıktır. Yine Arap turistlerin büyük çoğunluğu ailesiyle ve eşiyle beraber tatile katılmışlardır ve Türkiye'de 10 günden fazla konaklama yaptıkları ortaya çıkmıştır. Arap turistlerin Türkler ile iletişim kurmaktan çekinmediği ve Türklerin birbirleri ile benzer tutumlara sahip olmadıklarını düşündükleri belirlenmiştir. Genel olarak yaş, eğitim, sosyo-ekonomik durum, cinsiyet ve etnik köken gibi demografik değişkenlerin, önyargı ile ilişkili olduğu ancak bu ilişkilerin önyargı kökeni hakkında nispeten daha az bilgi vermekte olduğu (Stephan ve Stephan, 1996) göz önünde bulundurulduğunda genel ifadelere katılım düzeyleri de önem arz etmektedir.

Arap turistler, Türklerin geleneklerine kendilerinden daha fazla değer verdiklerini ve Türkler ile birbirilerinden farklı aile değerlerine sahip olduklarını düşünmektedirler. Ayrıca, Türklere ortak kullanım alanlarında ayrımcılık yapıldığı ve Türklerin geleneklerine kendilerinden daha fazla değer verdikleri yönünde görüş belirttikleri ortaya çıkmıştır. Bunun yanında Arap turistlerin, Türklerin gürültülü ve önyargılı olduklarını düşündükleri de belirlenmiştir. Türkler tarafında eleştirildiğini ifade eden Arap turistler Türkler ile sorunlu bir geçmişlerinin olduğunu düşündükleri ortaya çıkmıştır.

Arap turistlerin Doğu Karadeniz Bölgesi'ni ziyaretleri boyunca algılamış oldukları bütünleşik tehditlerin, Türklere karşı önyargılı davranmalarına neden olduğunu ifade etmek mümkündür. Stephan ve Stephan'ın (1996) da vurguladığı gibi; önyargı tüm dünyada var olan büyük bir sosyal sorundur ve bununla birlikte kalıp yargılar ile önyargılar kültürlerarası iletişimde engel teşkil etmektedir. Bu doğrultuda her birey, karşısındaki kişinin davranışlarını kendi kültürünün kurallarına göre değerlendirdiğinde, hakkında değerlendirilme yapılan birey hakkında genellikle olumsuz düşünceler ve önyargılar geliştirmektedir. Kültürün etkisiyle birlikte bireylerin oluşturmuş olduğu bu önyargılar da kültürlerarası iletişimde sorunların yaşanmasına neden olmaktadır.

Önyargıları değiştirmenin etkili yollarından biri de karşı grubun ait olduğu ortamda belirli bir zaman dilimi geçirerek onları ve bulundukları ortamı tanımak ve öğrenmektir. Gruplar arasındaki önyargıların kaynağı; birbirleri hakkındaki yanlış inançlara bağlı olarak birbirlerini yeterince tanımamalarıdır. Bu kapsamda; grupların karşlıklı bir iletişim ortamında anlaşmazlıklarını gidermeleri sağlanabilir. Aynı zamanda kültürlerarası iletişimi güçlendirebilmek adına; toplumlar arasında teknoloji ve sanat alanlarında kültürel değerlerin alışverişi ile sosyal ilişkiler oluşturularak önyargıların azaltılması yoluna gidilebilir (Saatcı, 2016). Allport (1962)'un da belirttiği gibi; farklı kültürel özelliklere sahip olan gruplar arasında 
iletişimlerini kuvvetlendirmek adına oluşturulacak temas, grupların etkileşimlerinden ziyade grupların karşılıklı olarak işbirliği içerisinde bulunabilecekleri gündelik etkinlikleri içermelidir. Bunun yanında gerçekleşmesi beklenen temas; gruplar arasında ortak bir çıkar kazanımı elde edilmesi üzerine kurulmalıdır ve ortak bir çıkar kazanılabilmesi için de gerekli olan koşullar önceden oluşturulmalıdır. Birbirleriyle temasta bulunacak olan gruplar eşit şartlarda ve eşit bir statüde yer almalıdırlar. Aksi takdirde eşit olmayan statülerde başlatılacak olan temas; kalıp yargıları doğrulayacak ve gruplararası önyargıları güçlendirebilecektir. Ayrıca gruplar arasında sağlanacak olan birleşme ve bütünleşme çabaları, resmi çerçevede oluşturulmalıdır ve kurumsal olarak da desteklenmelidir. Böylelikle gruplar kendilerini daha güvende hissederek karşılıklı iletişimlerinden ve etkileşimlerden olumlu sonuçlar alabileceklerdir. Gruplararası ilişkilerde farklı bir problem olarak ortaya çıkan; yetersiz iletişimin bir başka sonucunun da yanlış anlamalar ve anlaşılmalar olduğunu vurgulayan Lippmann (1998); yanlış anlamaların ve anlaşılmaların ortadan kalkmasını sağlayacak bilgilerin, kalıp yargılar ve önyargıların olumsuz etkilerinden uzak, etkin bir iletişim süreciyle gerçekleşebileceğinin altını çizmiştir.

Turizmin insanlığa sağladığı önemli katkılarından birinin de kültürlerarası uyumlaşmada gösterdiği başarı olduğunu ifade eden Rızaoğlu (2012), turizmin bu başarısının ülkeler arasında sağlanan etkin işbirliği ile daha da arttırılabileceğine vurgu yapmıştır. Yu ve Lee (2014); kültürlerarası turist etkileşimlerinin ve turist tutumlarının, doğrudan turist memnuniyetini etkileyen önemli bir değişken olarak ifade etmişlerdir. Bu bağlamda kültürel farklılıkları anlamak ve ona uygun stratejiler geliştirmek turizm sektörü için önemlidir (Landauer, Haider ve Pröbstl-Haider, 2013). Özellikle farklı kültürlere ev sahipliği yapan otel işletmelerinde, düzenlenecek olan ortak animasyon programları kapsamında sanatsal ve kültürel faaliyetler ve/veya ortak yemekler, grupların etkileşim ve iletişimlerinin güçlenmesini sağlayabilecektir.

Ülkelerin ikili ilişkilerinin durumunun da turizm olayına direkt etkisi olduğu göz önünde bulundurulduğunda; ülkeler en fazla turist çektikleri ya da en fazla turist gönderdikleri kültürler hakkında vatandaşlarına ve turizm olayına katkısı olan tüm taraflara eğitimler düzenleyebilirler. Böylelikle hem gelen turistlerin hem de turizm olayına katılan vatandaşlarının kültürlerarası uyumlarından dolayı memnuniyet düzeyleri arttırılabilecektir. Farklı kültüre sahip bireyler arasında oluşabilecek önyargıların azaltılması için etkileşim halinde bulunabilecekleri gruplar hakkında, grupları tanımlayıcı ve önyargıları azaltıcı kültürel eğitimler verilebilir. Kültürel eğitimler; kültür ve kültürel farkl1lıklar üzerine bilgilendirme, grubun kendi kültürlerinin gündelik yaşama yansımaları, farklı kültürel özelliklere sahip kişilerin davranışlarının nedenleri ve davranışların nasıl yorumlanacağı, grup içi paylaşımlar ve olay analizleri, örnek birkaç kültür üzerinden ayrıntılı bilgilendirme ve grup içi analiz yapılımı şeklinde gerçekleştirilebilir (Genç, 2014).

Bu araştırma, Doğu Karadeniz Bölgesi'ni ziyaret eden Arap turistlerin özellikleri ve görüşleri ile sınırlıdır. Dolayısıyla ileride yapılacak olan araştırmalara, ev sahibi olan toplum ile misafir olan toplumların karşılaşmaları esnasındaki tutumları ve önyargılarının da karşılaştırmalı olarak saptanması önerilmektedir.

\section{KAYNAKÇA}

Aberson, C. L. and Gaffney, A. M. (2008). An Integrated Threat Model of Explicit and Implicit Attitudes. European Journal of Social Psychology, 39: 808 - 830.

Allport, G. (1954). The Nature of Prejudice. Cambridge: Addison Wesley Publishing Company.

Avcıkurt, C. (2015). Turizm Sosyolojisi, Genel ve Yapısal Yaklaşım. (4. Baskı), Ankara: Detay Yayıncilik. 
Aydın, K. (2007). Uluslararası ve Küresel Pazarlamada Kültürel Etkiler. (2. Baskl), Ankara: Nobel Yayın Dağıtım.

Bayık Temel, A. (2011). Çok Kültürlülük ve Kültürlerarası İletişımin Sağlık Hizmetlerinin Sunumuna Etkileri, (Editörler) Esen, E. ve Yazıcı, Z.: Onlar Bizim Hemşehrimiz Uluslararası Göç ve Hizmetlerin Kültürlerarası Açılımı içinde Ankara: Siyasal Kitabevi.

Bayram, Y. (2016). Türk-Arap İlişkileri Bağlamında Türk Toplumunda Değişen Arap İmajının Turizme Yönelik Haber Çerçevelerinde Temsili, Uluslararası Sosyal Araştırmalar Dergisi, 9(43): 1683-1697.

Çeken, H., Özdemir Yılmaz, G. ve Ertürk, N. (2018). Arap Ülkelerinden Gelen Turistlerin Etkilerine Yönelik Yerel Halkın Algısı: Sapanca Örneği, Trakya Üniversitesi Sosyal Bilimler Dergisi, 20(1): 401-414.

Çuhadar Gürkaynak, E. (2012). Toplumsal Temas: Önyarg1 ve Ayrımcıllğı Önlemek İçin Bir Sosyal Değişim Aracı Olarak Kullanılabilir mi?, (Editörler) Çayır K. ve Ayan Ceyhan, M. : Ayrımcılık Çok Boyutlu Yaklaşımlar içinde İstanbul: İstanbul Bilgi Üniversitesi Yayınları.

DOKA (Doğu Karadeniz Kalkınma Ajansı). (2015). Doğu Karadeniz Bölgesinde Arap Turizmi, Mevcut Durum ve Gelişme Stratejisi Raporu, http://www.doka.org.tr/TR/Yayinlar/SektorRaporlari-Serisi adresinden 10 Mayıs 2018'de alınmıştır.

Genç, R. (2014). Uluslararası Otel ve Restoran Yönetimi (Illkeler, Kavramlar, Uluslararası Kaide ve Kurallar). (1. Baskı), Ankara: Detay Yayıncilık.

Gonzales, K. V., Verkuyten, M., Weesie, J. and Poppe, E. (2008). Prejudice Towards Muslims in The Netherlands: Testing Integrated Threat Theory, British Journal of Social Psychology, 47: 667685.

Hsu, S., Woodside, A. G. and Marshall, R. (2013). Critical Tests of Multiple Theories of Cultures' Consequences: Comparing the Usefulness of Models by Hofstede, Inglehart and Baker, Schwartz, Steenkamp, as well as GDP and Distance for Explaining Overseas Tourism Behavior, Journal of Travel Research, 52(6): 679 - 704.

http://yigm.ktb.gov.tr/TR-201114/yillik-bultenler.html, [Erişim Tarihi: 10.06.2019].

Landauer, M., Haider, W. and Pröbstl-Haider, U. (2013). The Influence of Culture on Climate Change Adaptation Strategies: Preferences of Cross-Country Skiers in Austria and Finland. Journal of Travel Research, 53(1): $96-110$.

Nawijn, J., Mitas, O., Lin, Y. and Kerstetter, D. (2012). How Do We Feel on Vacation? A Closer Look at How Emotions Change over the Course of a Trip, Journal of Travel Research, 52(2): 265274 .

Paolini, S., Hewstone, M., Cairns, E. and Voci, A. (2004). Effects of Direct and Indirect CrossGroup Friendships on Judgments of Catholics and Protestants in Northern Ireland: The Mediating Role of an Anxiety-Reduction Mechanism, Personality and Social Psychology Bulletin, 30: 770-788.

Pettigrew, T. F. (1998). Intergroup Contact Theory, Annual Review Psychology, 49: 65-85.

Redmond, B. F. (2013). Intergroup Theories (Integrated Threat, Socia Identity and Social Dominance. [Online] https://wikispaces.psu.edu/pages/viewpage.action?pageId=41095610 [Erişim Tarihi: 15.12.2018] 
Reisinger, Y. and Crotts, J. C. (2010). Applying Hofstede's National Culture Measures in Tourism Research: Illuminating Issues of Divergence and Convergence, Journal of Travel Research, 49(2): 153-164.

Reisinger, Y. and Turner, L. (1997). Cross-Cultural Differences in Tourism: Indonesian Tourists in Australia, Tourism Management, 18(3): 139-147.

Rızaoğlu, B. (2012). Turizm Davranışı. (3. Baskı). Ankara: Detay Yayıncılık.

Ruggiero, V. R. (2013). Sosyolojik Düşünme, Pratik Uygulama Kitabı. (Çev. Ali Arslan), (1. Baskı), İstanbul: Alioğlu Matbaacıllk.

Saatcl, G. (2016). Kültürlerarası Turist Tutumları: Bütünleşik Tehdit Teorisi Çerçevesinde Bir Araştırma, Yayımlanmamış Doktora Tezi, Balıkesir Üniversitesi, Balıkesir.

Stephan, C. W., Stephan, W. G., Demitrakis, K. M., Yamada, A. M. and Clason, D. L. (2000). Women's Attitudes Toward Men: An Integrated Threat Theory Approach, Psychology of Women Quarterly, 24: 63-75.

Stephan, W. G. and Renfro, L. (2002). The Role of Threat in Intergroup Relations, (Edt.) Mackie, D. and Smith, E.: In from Prejudice to Intergroup Emotions: Differentiated Reactions to Social Groups (pp. 265-283) New York: Psychology Press.

Stephan, W. G. and Stephan, C. W. (1996). Predicting Prejudice, International Journal of Intercultural Relations, 20: 409-426.

Stephan, W. G., Ybarra, O. and Bachman, G. (1999). Prejudice Toward Immigrants, Journal of Applied Social Psychology, 29(11): 2221-2237.

Stephan, W. G., Ybarra, O. and Morrison, K. R. (2007). Intergroup Threat Theory, (Edt.) Nelson, T.: In Handbook of Prejudice, New Jersey: Lawrence Erlbaum.

Tayeb, M. H. (1994). Organizations and National Culture: Methodology Considered, Organization Studies, 15(3): 429-446.

Ural, A. ve Kılıç, İ. (2013). Bilimsel Araştırma Süreci ve SPSS ile Veri Analizi. (Gözden Geçirilmiş ve Genişletilmiş 4. Baskı), Ankara: Detay Yayıncılık.

Urry, J. (2009). Turist Bakışı. (Çev. Enis Tataroğlu ve İbrahim Yıldız). (1. Baskı). Ankara: BilgeSu Yayincilik.

Ward, C. and Berno, T. (2011). Beyond Social Exchange Theory Attitudes Toward Tourists, Annals of Tourism Research, 38(4): 1556-1569.

Yu, J. and Lee, T. J. (2014). Impact of Tourists' Intercultural Interactions, Journal of Travel Research, 53(2): 225-238. 